\title{
No TREATment with Darbepoetin Dosed to Hemoglobin 13 Grams per Deciliter in Type 2 Diabetes with Pre-Dialysis Chronic Kidney Disease - Safety Warnings for Erythropoiesis-Stimulating Agents
}

\author{
Frederic R. Curtiss, PhD, RPh, CEBS, and Kathleen A. Fairman, MA
}

$\mathrm{I}$ n what a key observer described as "another example... where an intervention to modify a surrogate endpoint failed to translate into the expected improvement in patient outcome,"1 Pfeffer et al. (October 2009) found a nearly 2-fold increased risk of stroke in patients with diabetes, anemia, and pre-dialysis chronic kidney disease (CKD) dosed with darbepoetin alfa to a target hemoglobin ( $\mathrm{Hb}$ ) of 13 grams per deciliter (gm per $\mathrm{dL}$ ). ${ }^{2}$ The Trial to Reduce Cardiovascular Events with Aranesp Therapy (TREAT) enrolled 4,038 patients from August 25, 2004, through December 4, 2007, and was completed on March 28, 2009, with median follow-up of 29.1 months. Comparing patients randomly assigned to treatment with darbepoetin alfa $(n=2,012)$ versus placebo $(n=2,026)$, investigators found a hazard ratio (HR) of 1.92 (95\% CI $=1.38-2.68, P<0.001)$ for an increased risk of stroke (absolute rate $=5.0 \%$ for darbepoetin alfa vs. 2.6\% for placebo). TREAT investigators also observed no significant reduction in the incidence of the 2 primary endpoint outcomes. Of the patients treated with darbepoetin alfa, 31.4\% $(n=632)$ experienced the primary composite endpoint of death from any cause, stroke or cardiovascular events (myocardial infarction [MI], heart failure or myocardial ischemia) compared with $29.7 \%(n=602)$ for placebo ( $\mathrm{HR}=1.05,95 \% \mathrm{CI}=0.94-1.17, \mathrm{P}=0.41)$. There was also no significant difference between the darbepoetin and placebo groups in the other primary composite endpoint of death or end-stage renal disease (ESRD), 32.4\% ( $\mathrm{n}=652)$ for darbepoetin alfa versus 30.5\% ( $\mathrm{n}=618$ ) with placebo ( $\mathrm{HR}=1.06,95 \% \mathrm{CI}=0.95-1.19, P=0.29$ ).

Just 1 week prior to the report by Pfeffer et al., published online on October 30, 2009, a report by Heinze et al. published online on October 23, 2009 found that dosing erythropoiesisstimulating agents (ESAs) to $\mathrm{Hb}$ concentrations greater than 12.5 gm per dL in renal transplant recipients was associated with increased mortality. ${ }^{3}$ Heinze et al. also found a nonlinear relationship between mortality and $\mathrm{Hb}$ concentration, with the increased risk of mortality significant at $\mathrm{Hb}$ concentrations greater than 14 gm per dL. This nonrandomized cohort study of 1,794 renal transplant recipients in the Austrian Dialysis and Transplant Registry who received a transplant between January 1, 1992, and December 31, 2004, and survived at least 3 months (median 5.6-year follow-up) found that the 10-year survival rate was 57\% in patients who received ESAs versus $78 \%$ in patients not treated with ESAs $(P<0.001)$. After adjustment for confounding, $\mathrm{Hb}$ levels less than $12.5 \mathrm{gm}$ per dL were associated with increased risk of mortality both in ESA-treated patients ( $\mathrm{HR}=4.7,95 \% \mathrm{CI}=2.1$ 10.5 for $11.0 \mathrm{gm}$ per dL vs. $12.5 \mathrm{gm}$ per $\mathrm{dL}$ ) and in patients not treated with $\mathrm{ESAs}(\mathrm{HR}=2.5,95 \% \mathrm{CI}=1.5-4.0)$. For patients with $\mathrm{Hb}$ levels of at least $12.5 \mathrm{gm}$ per $\mathrm{dL}$, an interaction between ESA use and $\mathrm{Hb}$ level was observed; Hb levels higher than $12.5 \mathrm{gm}$ per $\mathrm{dL}$ were associated with increased mortality in ESA-treated patients $(\mathrm{HR}=2.8,95 \% \mathrm{CI}=1.0-7.9$ for $14.0 \mathrm{gm}$ per $\mathrm{dL}$ vs. 12.5 gm per $\mathrm{dL})$ but not in patients not treated with $\mathrm{ESAs}(\mathrm{HR}=0.7$, 95\% CI=0.4-1.5). These findings precipitated the recommendation by the authors that renal transplant patients with Hb concentration greater than $12.5 \mathrm{gm}$ per dL should not receive ESAs.

\section{Overwhelming Evidence That Harm Often Outweighs Benefits from the Use of ESAs in CKD}

Since March 2007, the product labels approved by the U.S. Food and Drug Administration (FDA) for epoetin alfa and darbepoetin alfa have included a black-box warning of an increased risk of death and serious cardiovascular events when these ESAs are dosed to a target $\mathrm{Hb}$ greater than $12 \mathrm{gm}$ per dL. ${ }^{4,5}$ Prior to the product label change on June 30, 2004, in which the indication for ESA in nondialysis patients with chronic renal failure and symptomatic anemia was limited to patients with Hb less than 10 gm per $\mathrm{dL},{ }^{6}$ the indication specified only that nondialysis patients with symptomatic anemia should have a hematocrit less than 30\%.7 The ESA product labels approved on November 8, 2007, expanded the black-box warning first introduced in March 2007 (Table 1) for dosing ESAs in patients with renal failure to higher Hb targets (13.5 vs. $11.3 \mathrm{gm}$ per dL and 14 vs. $10 \mathrm{gm}$ per dL) and to specify that dosing should be individualized to achieve and maintain $\mathrm{Hb}$ levels within the range of 10 to $12 \mathrm{gm}$ per dL. ${ }^{8}$ Publication in November 2006 of the results from the CHOIR (Correction of Hemoglobin and Outcomes in Renal Insufficiency) and CREATE (Cardiovascular Risk Reduction in Early Anemia Treatment With Epoetin Beta) study groups provided the evidence and impetus for these label changes for dosing ESAs more carefully and to lower $\mathrm{Hb}$ targets. The FDA news release on March 8, 2007 included the FDA opinion that "the new information applies to all ESAs, which share the same mechanism of action." The FDA also noted that "safety concerns from earlier ESA studies were discussed during a 2004 meeting of the [Oncologic Drugs Advisory Committee]," and "product 


\section{No TREATment with Darbepoetin Dosed to Hemoglobin 13 Grams per Deciliter in Type 2 Diabetes with Pre-Dialysis Chronic Kidney Disease - Safety Warnings for Erythropoiesis-Stimulating Agents}

\section{TABLE 1 Safety Warning Signals for Serious Adverse Effects of Erythropoiesis-Stimulating Agents}

Safety Warning Source

Epoetin product label July $1999^{7}$

\section{Epoetin product label} June 20046

CHOIR,

November 2006

(Singh et al.) ${ }^{10}$

CREATE,

November 2006

(Drueke et al.)11

\section{NCCN updates guideline} for cancer treatment-

related anemia,

March 5, $2007^{22}$

March 8, 2007

FDA first black-box warning for ESAs added to the labels ${ }^{4}$

\section{Summary}

The product label includes 2 warnings regarding thrombotic events and increased mortality: (a) 35\% mortality in cardiac disease patients treated to target hematocrit of $42 \%$ versus $29 \%$ mortality for the $30 \%$ target hematocrit, and (b) $5.6 \%$ mortality (vs. $0 \%$ for placebo) in patients without chronic renal failure undergoing coronary artery bypass graft surgery

The results from the BEST study are added to the product label for 939 women with MBC receiving chemotherapy who experienced higher mortality ( $8.7 \%$ vs. $3.4 \%$ for placebo), more fatal thrombotic vascular events ( $1.1 \%$ vs. $0.2 \%$ for placebo) and death attributed to disease progression ( $6.0 \%$ vs. $2.8 \%$ for placebo); Hb was targeted to 12 to $14 \mathrm{gm}$ per dL.

Comparison of $2 \mathrm{Hb}$ target levels in patients with CKD and anemia: Hb target of 13.5 gm per dL ( $\mathrm{n}=715$; high-Hb group) versus $\mathrm{Hb}$ target of $11.3 \mathrm{gm}$ per $\mathrm{dL}$ ( $\mathrm{n}=717$; low Hb-group): the primary endpoint (composite of death, MI, hospitalization for congestive heart failure [without renal replacement therapy] and stroke) over a median follow-up period of 16 months showed 125 events (17.5\%) in the high-Hb group vs. 97 events (13.5\%) in the low-Hb group ( $\mathrm{HR}=1.34,95 \% \mathrm{CI}=1.03-1.74, P=0.03$ ). Serious adverse events were more common in the high-Hb group $(n=376,54.8 \%)$ compared with the low-Hb group $(n=334$, $48.5 \% ; P=0.02$ ), and there were no significant differences between the 2 groups on summary quality-of-life measures. Comparison of 2 target $\mathrm{Hb}$ levels in patients with stage 3 or stage 4 CKD and baseline $\mathrm{Hb}$ of 11.0 to 12.5 gm per dL: 301 patients in the high-Hb group (13.0 to 15.0 gm per dL) experienced 58 (19.3\%) primary endpoint events (composite of 8 cardiovascular outcomes including MI, sudden death, stroke) versus 47 events (15.6\%) in the low-Hb group (10.5 to 11.5 gm per $\mathrm{dL}$ ) over the mean follow-up of 3 years ( $\mathrm{HR}=0.78,95 \% \mathrm{CI}=0.53-1.14, P=0.20)$. The higher Hb-target group also had more patients who started dialysis than did the lower-Hb target group $(42.2 \%$ vs. $36.8 \%$, respectively, $P=0.03$ ).

Addition to the Adverse Effects of Erythropoietic Therapy in the NCCN guideline: physicians are advised not to administer ESAs to patients with cancer-related anemia who are not on chemotherapy or radiation therapy (because a manufacturer-sponsored study showed higher mortality in the group that received darbepoietin)

"Use the lowest dose of EPOGEN that will gradually increase the hemoglobin concentration to the lowest level sufficient to avoid the need for red blood cell transfusion (see DOSAGE AND ADMINISTRATION). EPOGEN and other erythropoiesis-stimulating agents (ESAs) increased the risk for death and for serious cardiovascular events when administered to target a hemoglobin of greater than 12 g/dL (see WARNINGS: Increased Mortality, Serious Cardiovascular and Thromboembolic Events).

Cancer Patients: Use of ESAs

- shortened the time to tumor progression in patients with advanced head and neck cancer receiving radiation therapy when administered to target a hemoglobin of greater than $12 \mathrm{~g} / \mathrm{dL}$;

- shortened overall survival and increased deaths attributed to disease progression at 4 months in patients with metastatic breast cancer receiving chemotherapy when administered to target a hemoglobin of greater than $12 \mathrm{~g} / \mathrm{dL}$;

- increased the risk of death when administered to target a hemoglobin of $12 \mathrm{~g} / \mathrm{dL}$ in patients with active malignant disease receiving neither chemotherapy nor radiation therapy. ESAs are not indicated for this population.

(See WARNINGS: Increased Mortality and/or Tumor Progression)

Patients receiving ESAs pre-operatively for reduction of allogeneic red blood cell transfusions: A higher incidence of deep venous thrombosis was documented in patients receiving EPOGEN who were not receiving prophylactic anticoagulation. Antithrombotic prophylaxis should be strongly considered when EPOGEN is used to reduce allogeneic red blood cell transfusions (see WARNINGS: Increased Mortality, Serious Cardiovascular and Thromboembolic Events)."

Revised black-box warning in product labels, November 8, $2007^{8}$

\section{"INCREASED MORTALITY, SERIOUS CARDIOVASCULAR and THROMBOEMBOLIC EVENTS, and TUMOR PROGRESSION}

Renal failure: Patients experienced greater risks for death and serious cardiovascular events when administered erythropoiesisstimulating agents (ESAs) to target higher versus lower hemoglobin levels (13.5 vs. $11.3 \mathrm{~g} / \mathrm{dL} ; 14 \mathrm{vs} .10 \mathrm{~g} / \mathrm{dL}$ ) in two clinical studies. Individualize dosing to achieve and maintain hemoglobin levels within the range of 10 to $12 \mathrm{~g} / \mathrm{dL}$.

Cancer:

- ESAs shortened overall survival and/or time-to-tumor progression in clinical studies in patients with advanced breast, head and neck, lymphoid, and non-small cell lung malignancies when dosed to target a hemoglobin of $\geq 12 \mathrm{~g} / \mathrm{dL}$.

- The risks of shortened survival and tumor progression have not been excluded when ESAs are dosed to target a hemoglobin of $<12 \mathrm{~g} / \mathrm{dL}$.

- To minimize these risks, as well as the risk of serious cardio- and thrombovascular events, use the lowest dose needed to avoid red blood cell transfusions.

- Use only for treatment of anemia due to concomitant myelosuppressive chemotherapy.

- Discontinue following the completion of a chemotherapy course.

Perisurgery: EPOGEN increased the rate of deep venous thromboses in patients not receiving prophylactic anticoagulation. Consider deep venous thrombosis prophylaxis.

(See WARNINGS: Increased Mortality, Serious Cardiovascular and Thromboembolic Events, WARNINGS: Increased Mortality and/or Tumor Progression, and DOSAGE AND ADMINISTRATION.)" 


\section{No TREATment with Darbepoetin Dosed to Hemoglobin 13 Grams per Deciliter in Type 2 Diabetes with Pre-Dialysis Chronic Kidney Disease - Safety Warnings for Erythropoiesis-Stimulating Agents}

\section{TABLE 1 Safety Warning Signals for Serious Adverse Effects of Erythropoiesis-Stimulating Agents}

(continued from previous page)

\begin{tabular}{|c|c|}
\hline Safety Warning Source & Summary \\
\hline $\begin{array}{l}\text { ASCO/ASH } 2007 \text { Clinical } \\
\text { Practice Update for } \\
\text { Use of Epoetin and } \\
\text { Darbepoetin, } \\
\text { January } 1,2008^{26}\end{array}$ & $\begin{array}{l}\text { There is no evidence of increased survival in chemotherapy patients treated with ESA. ESA treatment should be discontinued } \\
\text { in the absence of response within 6-8 weeks. There is insufficient evidence to justify initiating ESAs at Hb levels greater than } \\
10 \text { gm per dL. Caution is advised against the use of ESA in cancer patients not receiving chemotherapy due to increased throm- } \\
\text { boembolic risks and decreased survival. }\end{array}$ \\
\hline $\begin{array}{l}\text { FDA Warning } \\
\text { January } 3,2008^{23}\end{array}$ & $\begin{array}{l}\text { Increased risk of rapid tumor growth and shortened survival from } 2 \text { new studies, in addition to the } 6 \text { studies in the revised } \\
\text { labeling in November 2007, in patients with breast, NSCLC, head and heck, lymphoid, or cervical cancers treated to the Hb } \\
\text { level of } 12 \mathrm{gm} \text { per dL or greater. }\end{array}$ \\
\hline $\begin{array}{l}\text { Systematic review of } \\
\text { VTE, tumor growth and } \\
\text { mortality in cancer- } \\
\text { associated anemia } \\
\text { (Bennett et al.) } \\
\text { February } 2008^{32}\end{array}$ & $\begin{array}{l}\text { Systematic review and meta-analysis of } 51 \text { Phase } 3 \text { clinical trials involving } 13,611 \text { cancer patients treated with ESAs versus pla- } \\
\text { cebo or usual care. Increased risk of VTE }(7.2 \% \text { vs. } 4.9 \%, \mathrm{RR}=1.57,95 \% \mathrm{CI}-1.31-1.87) \text { and increased mortality risk (HR=1.10, } \\
95 \% \mathrm{CI}=1.01-1.20) .8 \text { clinical trials published between } 2003 \text { and } 2008 \text { found increased rates of tumor progression or mortality } \\
\text { with ESA use. }\end{array}$ \\
\hline $\begin{array}{l}\text { Darbepoetin safety label } \\
\text { change order from FDA, } \\
\text { July } 30,2008^{29}\end{array}$ & $\begin{array}{l}\text { Removal of conditions on the product label to more clearly indicate the increased risk of mortality and poor tumor outcomes } \\
\text { when ESAs are given to patients receiving chemotherapy for certain types of cancer; and indicate that (a) darbepoetin is not } \\
\text { indicated for patients receiving myelosuppressive therapy when the anticipated outcome is cure, (b) therapy should not be initi- } \\
\text { ated at } \mathrm{Hb} \text { levels } \geq 10 \mathrm{gm} \text { per } \mathrm{dL} \text {, and (c) withhold dose when "Hb exceeds a level needed to avoid transfusion." }\end{array}$ \\
\hline $\begin{array}{l}\text { EPO Stroke Trial Group, } \\
\text { October } 15,2009 \\
\text { (Ehrenreich et al.) }\end{array}$ & $\begin{array}{l}\text { Overall death rate of } 16.4 \%(\mathrm{n}=42 \text { of } 256) \text { in the epoetin group versus } 9.0 \%(\mathrm{n}=24 \text { of } 266) \text { in the placebo group }(\mathrm{OR}=1.98,95 \% \\
\mathrm{CI}=1.16-3.38, P=0.01) \text { in this double-blind, placebo-controlled, randomized multicenter trial (Phase II/III; ClinicalTrials.gov } \\
\text { Identifier: NCT00604630) designed to evaluate efficacy and safety of epoetin in stroke. }\end{array}$ \\
\hline $\begin{array}{l}\text { Heinze et al., } \\
\text { October } 23,2009^{3}\end{array}$ & $\begin{array}{l}\text { Retrospective cohort study of } 1,794 \text { kidney transplant recipients (transplant between January } 1,1992 \text {, and December } 31,2004 \text { ) } \\
\text { in the Austrian Dialysis and Transplant Registry. Hb levels higher than } 12.5 \text { gm per dL were associated with increased mortality } \\
\text { in ESA-treated patients }(\mathrm{HR}=2.8,95 \% \mathrm{CI}=1.0-7.9 \text { for } 14.0 \text { gm per dL vs. } 12.5 \text { gm per dL) but not in patients not treated with } \\
\text { ESAs (HR }=0.7,95 \% \mathrm{CI}=0.4-1.5) \text {. }\end{array}$ \\
\hline $\begin{array}{l}\text { TREAT, } \\
\text { October 30, } 2009 \\
(\text { Pfeffer et al. })^{2}\end{array}$ & $\begin{array}{l}\text { Increased risk of stroke }(5.0 \% \text { vs. } 2.6 \% \text { for placebo, } \mathrm{HR}=1.92) \text { and no advantage in reduced risk of death, ESRD. or endpoint } \\
\text { cardiovascular events in } 2,012 \text { patients with diabetes and chronic kidney disease not on dialysis and darbepoetin dosed to target } \\
\mathrm{Hb} 13 \mathrm{gm} \text { per dL compared with placebo }(\mathrm{n}=2,026) \text {. }\end{array}$ \\
\hline $\begin{array}{l}\text { Hershman et al., } \\
\text { November 10, } 200933\end{array}$ & $\begin{array}{l}\text { Observational study of patients who were aged } 65 \text { years or older in the SEERs-Medicare database and diagnosed with colon, } \\
\text { NSCLC, breast cancer or with diffuse large B-cell lymphoma from January } 1,1991 \text {, through December } 31,2002 \text { and who received } \\
\text { chemotherapy. Of } 56,210 \text { patients treated with chemotherapy from } 1991 \text { through } 2002,15,346(27.3 \%) \text { received ESA. The pro- } \\
\text { portion of patients receiving ESAs increased from } 4.8 \% \text { in } 1991 \text { to } 45.9 \% \text { in } 2002(P<0.001) \text {, but the rate of blood transfusions } \\
\text { per year did not change }(22 \%) \text { from } 1991 \text { through } 2002 \text {. VTE occurred in } 1,796(14.3 \%) \text { of the } 12,522 \text { ESA patients versus } 3,400 \\
(9.8 \%) \text { of the } 34,820 \text { patients who did not (HR }=1.93,95 \% \text { CI }=1.79 \text { to } 2.07) \text {. Overall survival was similar in both groups. }\end{array}$ \\
\hline
\end{tabular}

ASCO/ASH = American Society of Clinical Oncology/American Society of Hematology; BEST = Breast Cancer Erythropoietin Survival Trial; CHOIR=Correction of

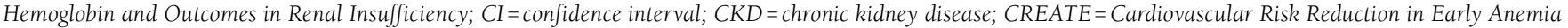
Treatment with Epoetin Beta; DVT= deep vein thrombosis; EPO = epoetin; $E S A=$ erythropoiesis-stimulating agent (epoetin, darbepoetin); ESRD =end-stage renal disease; FDA =U.S. Food and Drug Administration; g/dL= grams per deciliter; gm per $\mathrm{dL}=$ grams per deciliter; $\mathrm{Hb}=$ hemoglobin; $\mathrm{HR}=$ hazard ratio; $M B C=$ metastatic breast cancer; $M I=$ myocardial infarction; NCCN = National Comprehensive Cancer Network; NSCLC=non-small cell lung cancer; RR=relative risk; SEER=Surveillance, Epidemiology, and End Results; TREAT = Trial to Reduce Cardiovascular Events with Aranesp Therapy; VTE = venous thromboembolism.

labeling was previously revised in 1997, 2004, and 2005 to reflect new safety information." ${ }^{9}$

In CHOIR, 715 patients with CKD and anemia were randomized to a target $\mathrm{Hb}$ of $13.5 \mathrm{gm}$ per $\mathrm{dL}$ and $717 \mathrm{CKD}$ patients to a $\mathrm{Hb}$ target of $11.3 \mathrm{gm}$ per $\mathrm{dL}$, with the primary endpoint defined as a composite of death, MI, hospitalization for congestive heart failure (without renal replacement therapy) and stroke. ${ }^{10}$ Over a median follow-up period of 16 months, there were 125 events (17.5\%) in the high-Hb group vs. 97 events (13.5\%) in the low-Hb group ( $\mathrm{HR}=1.34,95 \% \mathrm{CI}=1.03-1.74, P=0.03)$. Serious adverse events, defined as "life-threatening, resulting in death, hospitalization, or substantial disability, or leading to a congenital anomaly or birth defect," were significantly more common in the high-Hb group $(n=376,54.8 \%)$ compared with the low-Hb group ( $\mathrm{n}=334,48.5 \% ; P=0.02$ ), including congestive heart failure ( $11.2 \%$ vs. $7.4 \%, P=0.02$ ), and there was no significant difference between the 2 groups on summary quality-of-life measures.

In CREATE, 603 patients with stage 3 or stage 4 CKD and $\mathrm{Hb}$ of 11.0 to 12.5 gm per $\mathrm{dL}$ were randomized to a target $\mathrm{Hb}$ value in the range from 13.0 to $15.0 \mathrm{gm}$ per $\mathrm{dL}$ (defined as "normal range," $\mathrm{n}=301$ ) or to the $\mathrm{Hb}$ range of 10.5 to $11.5 \mathrm{gm}$ per dL (defined as "subnormal," $\mathrm{n}=302$ ). ${ }^{11}$ The higher-range group received epoetin immediately at randomization, and the lower-range group received epoetin after $\mathrm{Hb}$ fell below $10.5 \mathrm{gm}$ per dL. The primary endpoint was the time to the first of 8 cardiovascular events (sudden death, MI, acute heart failure, stroke, transient ischemic attack, angina pectoris resulting in hospitalization for 24 hours or more or prolongation of hospitalization, 


\section{No TREATment with Darbepoetin Dosed to Hemoglobin 13 Grams per Deciliter in Type 2 Diabetes with Pre-Dialysis Chronic Kidney Disease - Safety Warnings for Erythropoiesis-Stimulating Agents}

complication of peripheral vascular disease [amputation or necrosis], or cardiac arrhythmia resulting in hospitalization for 24 hours or more). Over the mean follow-up of 3 years, there were 58 primary endpoint events (19.3\%) in the higher ("normal") Hb-target group versus 47 events (15.6\%) in the lower Hb-target group $(\mathrm{HR}=0.78,95 \% \mathrm{CI}=0.53-1.14, P=0.20)$. The higher Hb-target group also had more patients who started dialysis than did the lower Hb-target group (42.2\% vs. 36.8\%, respectively, $P=0.03)$. However, improvements in general health and physical function were greater in the higher Hb-target group than the lower Hb-target group ( $P=0.003$ and $P<0.001$, respectively). There was no significant difference between the 2 groups in the incidence of combined adverse effects. In other words, the CREATE trial showed that dosing epoetin to the higher Hb-target level (13.0 to 15.0 gm per $\mathrm{dL}$ ) did not reduce the risk of cardiovascular events and was associated with an increased risk of earlier dialysis.

\section{Previously Accepted Hb Targets No Longer Considered Reasonable}

In this issue of JMCP, Horowitz et al. report an analysis of the dose relationship between epoetin alpha and darbepoetin alfa in nondialyzed patients with CKD who were using epoetin alfa at baseline and subsequently switched to darbepoetin alfa. ${ }^{12}$ The data for this analysis were obtained for the subset of patients not on dialysis in an unpublished clinical trial (ClinTrial.gov identifier NCT00093977). ${ }^{13}$ NCT00093977 was a 52-week, multicenter, single-arm, open-label study of dialyzed and nondialyzed patients whose primary purpose was to investigate the safety of darbepoetin alfa. All subjects in this clinical trial were diagnosed with CKD (estimated glomerular filtration rate from 15 to 60 milliliters per minute per 1.73 square meters of body surface area as determined by the Modification of Diet in Renal Disease 4-variable equation), ${ }^{30,31}$ were currently on ESA therapy with $\mathrm{Hb}$ levels between 11.0 and $13.0 \mathrm{gm}$ per $\mathrm{dL}$, had transferrin saturation level of at least $15.0 \%$, and were clinically stable. Exclusion criteria included uncontrolled hypertension, acute myocardial ischemia, stroke, or major surgery within 3 months prior to screening. ${ }^{10,11}$ The first subject in NCT00093977 (also referred to as study 20040180) was enrolled November 4, 2004, and the last subject observation was October 25, 2006. ${ }^{14}$

NCT0009377 was completed at about the time that the CHOIR and CREATE study results were published in November 2006 and prior to the revised FDA product labeling for epoetin and darbepoetin for increased risk of death and serious cardiovascular risks when dosed to a target $\mathrm{Hb}$ greater than $12 \mathrm{gm}$ per $\mathrm{dL}$. The frequency and speed of $\mathrm{Hb}$ target changes during the past few years raise the question of whether the dose conversion ratios calculated by Horowitz et al. based on an outdated Hb target are informative for payers today. As Horowitz et al. observe, the specific dose conversion ratio for any sample must be determined empirically using data for that sample. Thus, in an era of changing $\mathrm{Hb}$ targets, the value of the Horowitz et al. study is primarily methodological. That is, the study illustrates an interesting mathematical method for calculation of dose conversation ratios when the dose relationship between 2 drugs is nonproportional. The mathematical method investigated by Horowitz et al., log-log analysis, should be considered in any situation in which nonproportional mathematical relationships are evident or suspected in the underlying data. ${ }^{15}$

\section{Increased Risk of Mortality in Chemotherapy Patients Treated with ESAs}

The results from TREAT for pre-dialysis patients and the research by Heinze et al. in renal transplant patients follow on the heels of a string of setbacks for the ESAs used to increase Hb levels in patients undergoing chemotherapy. In a previous issue of JMCP, Nordstrom et al. reviewed the history of the FDA actions in response to the evidence of shortened overall survival and time to tumor progression in patients with a wide range of cancers treated to a target $\mathrm{Hb}$ of $12 \mathrm{gm}$ per $\mathrm{dL}$ or more. ${ }^{16}$ Epoetin was first approved by the FDA on June 1, 1989, for patients with chronic renal failure to reduce the need for blood transfusions and later approved by the FDA in April 1993 for "the treatment of anemia in patients with non-myeloid malignancies where anemia is due to the effect of concomitantly administered chemotherapy," to "reduce the need for transfusions in patients who will be receiving chemotherapy for a minimum of two months."17 Potential harm with ESAs became evident in $2003^{18}$ when Henke et al. reported shorter progression-free survival and overall survival in the epoetin group compared with placebo in patients with head or neck cancer. ${ }^{19}$ In 2005, Leyland-Jones et al. reported the results of BEST (Breast Cancer Erythropoietin Survival Trial) in which survival at 1 year was lower in the epoetin group, ${ }^{20}$ and the BEST results were added to the product label (Table 1).

The FDA changed the labeling of epoetin again in March 2007 to add warnings that were updated in November 2007 to include instructions that (a) ESAs should be used only to treat anemia that occurs in patients with cancer while they are undergoing chemotherapy; (b) treatment with ESAs should be stopped when chemotherapy ends; and (c) dosing ESAs to an $\mathrm{Hb}$ target of $12 \mathrm{gm}$ per $\mathrm{dL}$ or greater has resulted in more rapid cancer progression or shortened overall survival in patients with breast, head and neck, lymphoid, cervical, and non-small cell lung malignancies (Table 1). ${ }^{8,21}$ The National Comprehensive Cancer Network (NCCN) revised its Cancer- and Anemia-Related Treatment Guidelines in March 2007, including the recommendation that ESAs not be used in patients with active cancer and anemia who are not receiving chemotherapy or radiation. The new recommendation was precipitated by a randomized controlled trial finding that darbepoetin was associated with higher mortality and failed to reduce red blood cell transfusions in these patients. ${ }^{22}$

On January 3, 2008, the FDA released another warning notice following submission of new data by the 2 ESA manufacturers obtained from 2 studies of ESAs that reinforced the results from 6 


\section{No TREATment with Darbepoetin Dosed to Hemoglobin 13 Grams per Deciliter in Type 2 Diabetes with Pre-Dialysis Chronic Kidney Disease - Safety Warnings for Erythropoiesis-Stimulating Agents}

previous studies of ESAs; "taken together, all 8 studies show more rapid tumor growth or shortened survival when patients with breast, non-small cell lung, head and neck, lymphoid or cervical cancers received ESAs compared with patients who did not receive this treatment. In all of these recent studies, ESAs were administered in an attempt to achieve a hemoglobin level of 12 grams per deciliter $(\mathrm{g} / \mathrm{dL})$ or greater, although many patients did not reach that level."23 In early March 2008, the FDA considered revocation of approval of the use of epoetin and darbepoeitin in cancer patients, finding that "there is insufficient safety data" to rule out serious risks to patients with any cancer except nonsmall cell lung cancer (NSCLC). ${ }^{24}$ The FDA Oncologic Drugs Advisory Committee (ODAC) recommended that ESAs be limited to use in chemotherapy patients with NSCLC (and not used in metastatic breast cancer or head and neck cancer), but could still be used in place of transfusions to treat anemia caused by chemotherapy in cancer patients if the patient and physician signed an informed consent form. ${ }^{25}$

In January 2008, the American Society of Clinical Oncology (ASCO) and the American Society of Hematology (ASH) advised that there was no evidence of increased survival in cancer patients with chemotherapy-related anemia who are treated with epoetin or darbepoetin and that there was insufficient evidence to support a benefit in fewer transfusions or improved quality of life from initiation of ESA therapy early in patients with $\mathrm{Hb}$ levels greater than 10 gm per $\mathrm{dL} .{ }^{26}$ The ASCO/ASH Clinical Practice Guideline Update also advised that ESAs should not be continued beyond 6-8 weeks in the absence of response in "nonresponders," contrary to the FDA-approved labels at the time.

Ultimately, the FDA did not impose a restrictive distribution program, revocation of FDA approval for the drugs in cancer patients, or limitation of the use of ESAs to cancer patients with NSCLC. However, on July 30, 2008, the FDA ordered the manufacturers of ESAs to change the labels to say that treatment should not begin until $\mathrm{Hb}$ falls to $10 \mathrm{gm}$ per $\mathrm{dL}$ and remove the language that suggested that it was safe to continue treating patients to an $\mathrm{Hb}$ concentration of $12 \mathrm{gm}$ per dL. ${ }^{27}$ The FDA reportedly could not reach agreement with the ESA manufacturers on the label warnings following the March 2008 meeting of the advisory committee and invoked authority under a 2007 law to impose language on the ESA labels that had previously implied that dosing to an $\mathrm{Hb}$ concentration of $12 \mathrm{gm}$ per $\mathrm{dL}$ was safe. This order by the FDA for the ESA label changes marked the first time that the agency had invoked this authority that it was granted in 2007,28 and the 3 critical demands removed the qualifying conditions to state explicitly that (a) "Aranesp is not indicated for patients receiving myelosuppressive therapy when the anticipated outcome is cure," (in the black box warning), (b) "therapy should not be initiated at hemoglobin levels > 10 g/dL," and (c) "withhold dose if: hemoglobin exceeds a level needed to avoid transfusion." 29

\section{Innocent Until Proven Guilty - Trick or TREAT?}

It is no longer permissible to presume safety in the use of ESAs to increase $\mathrm{Hb}$ levels in the interest of avoiding blood transfusions in patients with anemia. This represents a profound shift in medical opinion. As pointed out by Pfeffer et al., it was not long ago that clinical trials of ESAs considered the use of placebo unnecessary or unethical because the benefits of ESAs were unquestioned. ${ }^{2}$ As observed by Dr. Harlan Krumholz, a cardiologist and director of the Yale-New Haven Hospital Center for Outcomes Research and Evaluation, "it is a shame that this information [the TREAT findings] lagged behind the enthusiastic adoption of this treatment strategy. The finding highlights the importance of testing our interventions for their effects on patient outcomes." ${ }^{\text {A }}$ A metaanalysis published as recently as 2 years ago (2007) found an increased risk of all-cause mortality associated with the dosing of ESA agents to higher $\mathrm{Hb}$ concentrations in CKD patients and found no placebo-controlled trials among all of the clinical trials including unpublished studies. ${ }^{30}$

Failure to conduct placebo-controlled trials contributed to masking the harm-versus-benefit relationship for the ESAs in CKD for more than 15 years. The scope of risk associated with the use of ESAs has grown profoundly larger as a result of publication of CHOIR and CREATE and now TREAT. It also noteworthy that the harms uncovered in TREAT did not involve cancer patients, who were excluded from that study.

With the publication of the TREAT trial results, we now know that ESAs are associated with a previously undocumented increased risk of stroke, at least in patients with CKD and not on dialysis. A coincident study by Ehrenreich et al. for the EPO Stroke Trial Group (ClinicalTrials.gov number NCT00211120) published online in mid-October 2009, just 2 weeks before the online publication of the TREAT study, investigated the use of intravenous ESA in a sample of early-phase acute ischemic stroke patients. ${ }^{31}$ The investigators found an unexpected overall death rate of $16.4 \%(n=42$ of 256$)$ in the epoetin group versus $9.0 \%$ $(n=24$ of 266) in the placebo group $(O R=1.98,95 \% C I=1.16$ 3.38; $P=0.01$ ). TREAT also confirmed previous evidence of an increased risk of venous thromboembolic events (VTEs) in patients treated with ESAs (41 patients in the darbepoetin group [2.0\%] vs. 23 patients with VTE in the placebo group [1.0\%, $P=0.02])^{2}$

The increased risks of VTE and mortality associated with ESAs were reported by Bennett et al. in early 2008 in a systematic review of published and unpublished studies through January 17 , $2008 .^{32}$ In the 51 phase 3 clinical trials involving 13,611 patients with survival information and 38 clinical trials involving 8,172 patients with information about VTEs studied by Bennett et al., a $57 \%$ increase in the relative risk of VTE was found in cancer patients who received ESAs (334 VTE events among 4,610 patients [7.2\%] treated with ESA vs. 173 VTE events among 3,562 control patients [4.9\%], relative risk $=1.57,95 \% \mathrm{CI}=1.31-1.87$ ), and increased mortality risks ( $\mathrm{HR}=1.10,95 \% \mathrm{CI}=1.01-1.20)$. 


\section{No TREATment with Darbepoetin Dosed to Hemoglobin 13 Grams per Deciliter in Type 2 Diabetes with Pre-Dialysis Chronic Kidney Disease - Safety Warnings for Erythropoiesis-Stimulating Agents}

The weight of the evidence of an increased risk of VTE events got heavier with the report by Hershman et al. in November 2009. In this observational analysis of administrative records for cancer patients aged 65 years or older, there was no difference in overall survival for patients who received ESAs but there was an increased risk of VTEs (14.3\% of 12,522 patients who received an ESA vs. $9.8 \%$ of the 34,820 patients who did not receive an ESA; $\mathrm{HR}=1.93,95 \% \mathrm{CI}=1.79-2.07){ }^{33}$

The recent clinical trial results from TREAT and the EPO Stroke Trial Group are convincing because the studies were sponsored by the manufacturer of epoetin and darbepoetin. The unexpected results from a clinical trial that was part of an effort to expand the use of ESAs to patients with acute ischemic stroke added to the avalanche of bad news for the market expansion of ESAs and to our confidence in this evidence in part because the CHOIR and CREATE clinical trials were also sponsored by the ESA marketers. ${ }^{34}$ And, the commercial interest in higher dosing of ESAs to higher $\mathrm{Hb}$ targets appears to have contributed to an inability of the FDA advisory committee in May 2007 to determine if ESAs have effects on survival or tumor promotion at the FDA-recommended doses rather than at $\mathrm{Hb}$ targets higher than 12 gm per $\mathrm{dL} .^{35}$

The publication of randomized controlled trial results with unexpected outcomes is critical to protection of patient safety. Higher levels of scrutiny are required for clinical guidelines such as the expansion of target $\mathrm{Hb}$ levels to 11.0 to $13.0 \mathrm{gm}$ per $\mathrm{dL}$ advocated by the National Kidney Foundation (NKF) in 2006 amid apparent conflict of interest introduced by "substantial financial support" from the manufacturers of ESAs and more than the 10 to $12 \mathrm{gm}$ per $\mathrm{dL} \mathrm{Hb}$ range approved by the FDA at the time. ${ }^{34}$ At the height of the controversy in 2007, the New England Journal of Medicine reportedly pulled an editorial by Robert Steinbrook, MD, that was critical of funding of the NKF by industry, and replaced it with an editorial by Remuzzi and Ingelfinger that concluded that it is wise to not correct anemia completely in CKD patients; ${ }^{36}$ Ingelfinger at the time was the immediate past president of the Massachusetts chapter of the NKF, a fact not disclosed in the editorial. ${ }^{37}$

Steinbrook has shined the spotlight on the matter of financial interests in the use of $\mathrm{ESAs},{ }^{35}$ noting that "dialysis facilities can make more money from administering epoetin than from dialysis and related routine services, which Medicare has reimbursed at a composite rate since 1983." ${ }^{38}$ In 2005, darbepoetin ranked first and epoetin ranked second among all Part B drugs in total expenditures. ${ }^{39}$ At a hearing in December 2006, the chairman of the House Ways and Means Committee announced that $40 \%$ of the dialysis patients treated with epoetin had Hb levels greater than $12 \mathrm{gm}$ per $\mathrm{dL}^{40}$ Since the mortality benefits of ESAs have never been proven, ${ }^{26,41}$ the increasing weight of the harms associated with ESAs combined with the nonlinear relationship between ESA drug cost and higher $\mathrm{Hb}$ concentrations, ${ }^{42}$ makes the valuefor-money calculation pretty anemic.

\section{Authors}

FREDERIC R. CURTISS, PhD, RPh, CEBS, is Editor-in-Chief, and KATHLEEN A. FAIRMAN, MA, is Associate Editor and Senior Methodology Reviewer of the Journal of Managed Care Pharmacy.

AUTHOR CORRESPONDENCE: Frederic R. Curtiss, PhD, RPh, CEBS, Academy of Managed Care Pharmacy, 100 North Pitt St., Suite 400, Alexandria, VA 22314. Tel.: 830.935.4319;

E-mail:fcurtiss@amcp.org.

\section{DISCLOSURES}

The authors report no conflicts of interest related to the subjects or products discussed in this article.

\section{REFERENCES}

1. Cardiobrief. Halloween trick: don't TREAT diabetes with ESAs. October 30, 2009. Available at: http://cardiobrief.org/2009/10/30/halloween-trickdont-treat-diabetes-with-esas/. Accessed November 12, 2009.

2. Pfeffer MA, Burdmann EA, Chen CY, et al., for the TREAT investigators. A trial of darbepoetin alfa in type 2 diabetes and chronic kidney disease. N Engl J Med. 2009;361 (online Oct. 30, 2009). http://content.nejm.org/cgi/ reprint/NEJMoa0907845.pdf

3. Heinze G, Kainz A, Horl WH, Oberbauer R. Mortality in renal transplant recipients given erythropoietins to increase haemoglobin concentration: cohort study. BMJ. 2009;339:b4018. Available at: http://www.bmj.com/cgi/ reprint/339/oct23_1/b4018. Accessed November 8, 2009.

4. U.S. Food and Drug Administration product label. Epogen (epoetin alfa for injection. March 8, 2007. Available at: http://www.accessdata.fda.gov/ drugsatfda_docs/label/2007/103234s5122lbl.pdf. Accessed November 8, 2009.

5. U.S. Food and Drug Administration. Public health advisory: erythropoiesis-stimulating gents (ESAs). March 9, 2007. Available at: http://www.fda. gov/ForConsumers/ByAudience/ForPatientAdvocates/HIVandAIDSActivities/ ucm124262.htm. Accessed November 9, 2009.

6. U.S. Food and Drug Administration product label. Epogen (epoetin alfa) for injection. June 30. 2004. Available at" http://www.accessdata.fda. gov/drugsatfda_docs/label/2004/103234_5053_Epogen_lbl.pdf. Accessed November 15, 2009.

7. U.S. Food and Drug Administration product label. Epogen (epoetin alfa) for injection. July 26, 1999. Available at: http://www.accessdata.fda.gov/ drugsatfda_docs/label/2000/epoamg072699lb.pdf. Accessed November 15 , 2009.

8. U.S. Food and Drug Administration product label. Epogen (epoetin alfa) for injection. November 8, 2007. Available at: http://www.accessdata.fda.gov/ drugsatfda_docs/label/2007/103234s5158lbl.pdf. Accessed November 15, 2009.

9. U.S. Food and Drug Administration. FDA strengthens safety information for erythropoiesis-stimulating agents (ESAs). FDA News Release P07-40. March 9, 2007. Available at: http://www.fda.gov/NewsEvents/Newsroom/ PressAnnouncements/2007/ucm108864.htm. Accessed November 15, 2009.

10. Singh AK, Szczech L, Tang KL, et al., for the CHOIR investigators Correction of anemia with epoetin alfa in chronic kidney disease. N Engl J Med. 2006;355(20):2085-98. Available at: http://content.nejm.org/cgi/ reprint/355/20/2085.pdf. Accessed November 8, 2009. 


\section{No TREATment with Darbepoetin Dosed to Hemoglobin 13 Grams per Deciliter in Type 2 Diabetes with Pre-Dialysis Chronic Kidney Disease - Safety Warnings for Erythropoiesis-Stimulating Agents}

11. Drueke TB, Locatelli F, Clyne N, et al., for the CREATE trial investigators. Normalization of hemoglobin level in patients with chronic kidney disease and anemia. N Engl J Med. 2006;355(20):2071-84. Available at: http:// content.nejm.org/cgi/reprint/355/20/2071.pdf. Accessed November 8, 2009.

12. Horowitz J, Agarwal A, Huang F, Gitlin M, Gandra SR, Cangialose CB. Empirical methods to calculate an erythropoiesis-stimulating agent dose conversion ratio in nondialyzed patients with chronic kidney disease. $J$ Manag Care Pharm. 2009;15(9):741-50.

13. ClinicalTrials.gov. Phase III clinical trial NCT00093977. Study to assess darbepoetin alfa in subjects with chronic kidney disease. Available at: http:// clinicaltrials.gov/ct2/show/NCT00093977?term=NCT00093977\&rank=1. Accessed November 9, 2009.

14. ClinicalTrialsFeeds.org. Study to assess darepoetin alfa in subjects with chronic kidney disease. Available at: http://clinicaltrialsfeeds.org/clinical-trials/show/NCT00093977, with study results at: http://download.veritasmedicine.com/REGFILES/amgen/08D_FDAMA_113_Posting_Summary_33_ NESP_20040180.pdf. Accessed November 9, 2009.

15. Fairman KA, Rucker ML. Fractal mathematics in managed care? How a simple and revealing analysis could improve the forecasting and management of medical costs and events. J Manag Care Pharm. 2009;15(4):351-58. Available at: http://www.amcp.org/data/jmcp/351-358.pdf

16. Nordstrom BL, Luo W, Fraeman KH, Whyte JL, Nordyke RJ. Use of erythropoiesis-stimulating agents among chemotherapy patients with hemoglobin exceeding 12 grams per deciliter. J Manag Care Pharm. 2008;14(9):858-69. Available at: http://www.amcp.org/data/jmcp/858-869. pdf.

17. U.S. Food and Drug Administration product label. Procrit epoetin alfa for injection. April 1993. Available at: http://www.accessdata.fda.gov/drugsatfda_docs/label/pre96/103234s1015_LBL.pdf. Accessed November 15, 2009

18. Khuri FR. Weighing the hazards of erythropiesis stimulation in patients with cancer. N Engl J Med. 2007;356(24):2445-48. Available at: http://content.nejm.org/cgi/reprint/356/24/2445.pdf. Accessed November 15, 2009.

19. Henke M, Laszig R, Rübe C, et al. Erythropoietin to treat head and neck cancer patients with anaemia undergoing radiotherapy: randomised, doubleblind, placebo-controlled trial. Lancet. 2003;362:1255-60.

20. Leyland-Jones B, Semiglazov V, Pawlicki M, et al. Maintaining normal hemoglobin levels with epoetin alfa in mainly nonanemic patients with metastatic breast cancer receiving first-line chemotherapy: a survival study. J Clin Oncol. 2005;23:5960-72. Available at: http://jco.ascopubs.org/cgi/ reprint/23/25/5960. Accessed November 15, 2009.

21. Steensma DP. Erythropoiesis stimulating agents. May not be safe in people with cancer. BMJ. 2007;334:648-69.

22. National Comprehensive Cancer Network. NCCN updates cancer- and anemia-related treatment guidelines. March 5, 2007. Available at: http:// www.nccn.org/about/news/newsinfo.asp?NewsID=98. Accessed November 15,2009

23. U.S. Food and Drug Administration. FDA receives new data on risks of anemia drugs: consistent with previous data on tumor growth and death. January 3, 2008. Available at: http://www.fda.gov/NewsEvents/Newsroom/ PressAnnouncements/2008/ucml16830.htm. Accessed November 9, 2009.

24. Mathews AW, Chase M. New anemia-drug restrictions possible - J\&J, Amgen brace for FDA advisory on approved uses. Wall Street J. Mar 12, 2008:D7.

25. Tanne JH. FDA committee recommends restricting use of anti-anaemia drug in cancer. BMJ. 2008;336:632.

26. Rizzo JD, Somerfield MR, Hargerty KL, et al. Use of epoetin and darbepoetin in patients with cancer: 2007 American Society of Clinical Oncology/ American Society of Hematatology clinical practice guideline update. J Clin Oncol. 2008;28(1):132-49. Available at: http://www.jco.ascopubs.org/cgi/ reprint/26/1/132. Accessed November 10, 2009
27. Pollack A. Amgen told to reword drug label. NY Times. July 31, 2008. Available at: http://www.nytimes.com/2008/07/31/business/3lamgen. html?_r=2\&th=\&adxnnl=1\&oref=slogin\&emc=th\&adxnnlx=1257879619KUHPsoZgply8MKfz2GMDYA. Accessed November 10, 2009.

28. Gryta T. Anemia drugs to carry wider warnings. Wall Street J. July 31, 2008. B5.

29. U.S. Food and Drug Administration. Complete response and safety labeling change order. STN: BL103951/5189. July 30, 2008 Available at: http://www.fda.gov/downloads/Drugs/DrugSafety/ PostmarketDrugSafetyInformationforPatientsandProviders/ucml10268.pdf. Accessed November 14, 2009.

30. Phrommintikul A, Haas SJ, Elsik M, Krum H. Mortality and target haemoglobin concentrations in anemic patients with chronic kidney disease treated with erythropoietin:a meta-analysis. Lancet. 2007;369(9559):381-88. Abstract available at: http://www.ncbi.nlm.nih.gov/pubmed/17276778.

31. Ehrenreich H, Weissenborn K, Prange H, et al., for the EPO Stroke Trial Group. Recombinant human erythropoietin in the treatment of acute ischemic stroke. Stroke. 2009 October 15 (Epub ahead of print). Abstract available at: http://www.ncbi.nlm.nih.gov/pubmed/19834012. Accessed November 8, 2009.

32. Bennett CL, Silver SM, Djulbegovic B, et al. Venous thromboembolism and mortality associated with recombinant erythropoietin and darbepoetin administration for the treatment of cancer-associated anemia. JAMA. 2008;299(8):914-24. Available at: http://jama.ama-assn.org/cgi/ reprint/299/8/914. Accessed November 9, 2009

33. Hershman DL, Buono DL, Malin J, McBride R, Tsai WY, Neugut AI. Patterns of use and risks associated with erythropoiesis-stimulating agents among Medicare patients with cancer. J Natl Cancer Inst. 2009; (online November 10, 2009). Abstract available at: http://jnci.oxfordjournals.org/cgi/ content/abstract/djp387. Accessed November 11, 2009.

34. Hamilton DP, Hechinger J. Research questions aggressive treatment for kidney patients. Wall Street J. Nov 16, 2006:D1, D4

35. Steinbrook R. Erythropoietin, the FDA, and oncology. N Engl J Med. 2007;356(24):2448-51.

36. Remuzzi G, Ingelfinger JR. Correction of anemia - payoffs and problems. N Engl J Med. 2006;355(20):2144-46.

37. Armstrong D. Medical journal spikes article of industry ties to kidney group. Wall Street J. Dec 26, 2006:B1,B4. Available at: http://www.commercialalert.org/news/archive/2006/12/medical-journal-spikes-article-on-industry-ties-of-kidney-group. Accessed November 13, 2009.

38. Steinbrook R. Medicare and erythropoietin. N Engl J Med. 2007;356(1):4-6.

39. U.S. Government Accountability Office. Report to the chairman, Committee on Ways and Means, House of Representatives, end-stage renal disease, bundling Medicare's payment for drugs with payment for all ESRD services would promote efficiency and clinical flexibility. GAO-07-77, November 2006. Available at: http://www.gao.gov/new.items/d0777.pdf Accessed November 14, 2009.

40. Chase M. Amgen's star fades amid safety questions. Wall Street J. April 10, 2007:Al, A9.

41. Treleaven DJ, Clase CM. Use of erythropoietins in patients with renal transplants: normalization of haemoglobin is hazardous, ineffective and costly. BMJ. 2009;339:b3825 (online October 23, 2009). Available at: http:// www.bmj.com/cgi/content/full/339/oct23_1/b3825. Accessed November 9, 2009.

42. Tonelli M, Winkelmayer WC, Jindal KK, Owen WF, Manns BJ. The costeffectiveness of maintaining higher hemoglobin targets with erythropoietin in hemodialysis patients. Kidney Int. 2003;64(1):295-304. Abstract available at: http://www.ncbi.nlm.nih.gov/pubmed/12787422. Accessed November 13, 2009. 